\title{
Itchy neck rings
}

\author{
Ashish Bhargava, ${ }^{\circledR 1,2}$ Babak Hooshmand ${ }^{1}$
}

${ }^{1}$ Internal Medicine, Ascension St John hospital, Grosse Pointe Woods, MI, USA

${ }^{2}$ Internal Medicine, Wayne State University, Detroit, MI, USA

\section{Correspondence to}

Dr Ashish Bhargava, drashishbhargava@gmail.com

Accepted 1 May 2019

\section{DESCRIPTION}

A 40-year-old woman with HIV presented to an outpatient clinic with a 5-day history of localised erythematous ring-shaped, papular and pruritic rash in the posterior aspect of the neck (figure 1). She had applied local cold compresses, but the rash worsened. Six weeks prior to her current presentation, she was started on a fixed-dose combination of elvitegravir, tenofovir alafenamide, emtricitabine and cobicistat. Her CD4 count rose from 15 to 62 cells per cubic mm and HIV viral load decreased from 98000 to 231 copies per mL. A clinical diagnosis of unmasking immune reconstitution inflammatory syndrome (IRIS) with cutaneous dermatophytes was made. The patient was treated with a 14-day course of topical terbinafine cream. At follow up, after 4 weeks of treatment, the rash had completely healed, except for outer post-inflammatory hyperpigmentation (figure 2).

IRIS occurs in response to subclinical infections, with rapid immune functional recovery, following the commencement of antiretroviral therapy (ART). Lower CD4 count or high HIV viral RNA at the time of initiating ART increases the risk for IRIS. ${ }^{1}$ Most patients develop symptoms within a week to few months after initiating ART. ${ }^{2}$ Clinical features depend on the type and location of pre-existing opportunistic lesions. In our patient, well-demarcated, annular, erythematous, pruritic lesion points towards dermatophyte infection. Clinical worsening with moisture adds to the nature of fungal lesions. Patient responded well with topical antifungal cream without interruption in antiretroviral

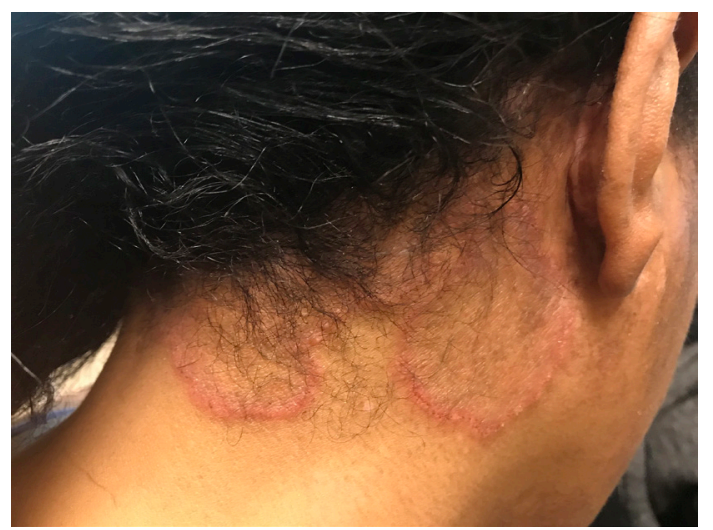

Figure 1 Rash on presentation.

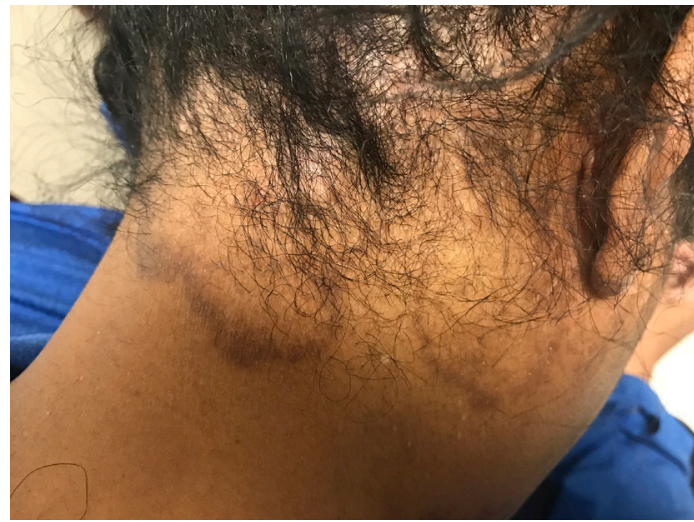

Figure 2 Rash after treatment.

\section{Learning points}

- Consider immune reconstitution inflammatory syndrome (IRIS) in a patient who presents with inflammatory process after initiating potent antiretroviral therapy (ART).

- When suspecting IRIS, focus on recognising and treating underlying opportunistic infections.

- Interruption to ART is only indicated in severe life-threatening cases of IRIS.

therapy. In our case, we did not use concomitant steroid therapy for the treatment of IRIS, but it should be considered in severe cases.

Contributors $A B$ : planning, reporting, conception, analysis and interpretation of data and design. BH: acquisition of data or analysis and interpretation of data.

Funding The authors have not declared a specific grant for this research from any funding agency in the public, commercial or not-for-profit sectors.

Competing interests None declared.

Patient consent for publication Obtained.

Provenance and peer review Not commissioned; externally peer reviewed.

\section{REFERENCES}

1 Grant PM, Komarow L, Andersen J, et al. Risk factor analyses for immune reconstitution inflammatory syndrome in a randomized study of early vs. deferred ART during an opportunistic infection. PLOS One 2010;5:e11416.

2 French MA, Lenzo $\mathrm{N}$, John $\mathrm{M}$, et al. Immune restoration disease after the treatment of immunodeficient HIV-infected patients with highly active antiretroviral therapy. HIV Med 2000;1:107-15. 
Images in...

Copyright 2019 BMJ Publishing Group. All rights reserved. For permission to reuse any of this content visit https://www.bmj.com/company/products-services/rights-and-licensing/permissions/

BMJ Case Report Fellows may re-use this article for personal use and teaching without any further permission.

Become a Fellow of BMJ Case Reports today and you can:

- Submit as many cases as you like

- Enjoy fast sympathetic peer review and rapid publication of accepted articles

Access all the published articles

- Re-use any of the published material for personal use and teaching without further permission

For information on Institutional Fellowships contact consortiasales@bmjgroup.com

Visit casereports.bmj.com for more articles like this and to become a Fellow 